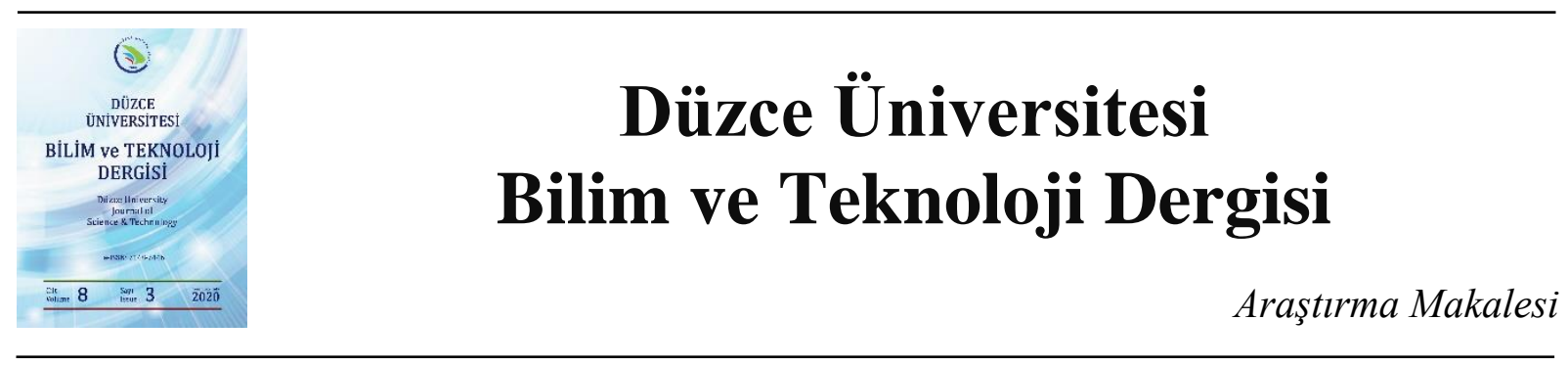

\title{
Meşe, Kayın Odunu ve Fındık Kabuğu Atıklardan Lentinus edodes (Şitaki) Mantarı Üretimi
}

\author{
Mesut YALÇIN ${ }^{\mathrm{a}}$, (D) Çağlar AKÇAY ${ }^{\mathrm{a}^{*}}$, (D) Gonca DÜZKALE SÖZBİR ${ }^{\mathrm{b}}$ \\ ${ }^{a}$ Orman Endüstri Mühendisliği Bölümü, Orman Fakültesi, Düzce Üniversitesi, Düzce, TÜRKIYYE \\ ${ }^{b}$ Orman Endüstri Mühendisliği Bölümü, Orman Fakültesi, Kahramanmaraş Sütçü İmam Üniversitesi, \\ Kahramanmaraş, TÜRKIYE \\ * Sorumlu yazarin e-posta adresi: caglarakcay@duzce.edu.tr
}

DOI : 10.29130/dubited.681542

\begin{abstract}
ÖZET
Bu çalışmanın amacı, bazı tarımsal artıklardan tıbbi olarak da kullanılma potansiyeli olan Lentinus edodes (Şitaki mantarı) mantarı üretmektir. Çalışmada, Düzce ilinde kereste artıklarından ortaya çıkan meşe ve kayın talaşı ile findık kabukları mantar yetiştirme ortamı olarak değerlendirilmiştir. Bu kapsamda, kullanılan fındık kabukları Wiley değirmeninde öğütülmüştür. Kayın ve meşe talaşları ise kereste işleyen bir fabrikadan hazır olarak temin edilmiştir. Odun talaşları ve findık kabukları belli oranlarda karıştırılarak kompostlar hazırlanmıştır. Hazırlanan kompostlar, $121^{\circ} \mathrm{C}$ ve 1.1 atm'de steril hale getirilmiştir. Şitaki mantar miseli aşılanan kompostlar $26^{\circ} \mathrm{C}$ sıcaklık ve $\% 80$ bağıl nem ortamında inkübasyon süresini tamamlamış sonrasında ise $5^{\circ} \mathrm{C}$ 'de bekletilip promordium oluşması için tekrar yetiștirme odasına alınmıştır. Özellikle \%100 findık kabuğu ile üretilen mantarların, meșe ve kayın talaşına göre verim bakımından daha düşük değerler verdiği tespit edilmiştir. Ancak findık kabuğunun diğer iki materyal ile 1:1 oranında karışımlarından elde edilen verimlilik ve biyolojik etkinlik değerleri yalnızca meşe ve kayın talaşından üretilen mantarlarınki ile yaklaşık aynı oran/değerlerdedir. En yüksek verimlilik ve biyolojik etkinlik değerleri meşe talaşı kompostundan elde edilmiştir. Kimyasal içerik sonuçlarına göre, findık kabuğu ve karışımları toplam azot ve protein bakımından en yüksek değerlere sahiptir. Toplam enerji, karbonhidrat ve yağ oranları bakımından ise kompost karışımları arasında önemli sayılabilecek farklılık tespit edilmemiştir.
\end{abstract}

Anahtar Kelimeler: Lentinus edodes (Şitaki), tıbbi mantar, findık kabuğu, kayın talaşı, meşe talaşı

\section{Cultivation of Lentinus Edodes (Shiitake) Mushroom from Oak, Beech Wood and Hazelnut Shell Wastes}

\begin{abstract}
The aim of this study was to cultivation Lentinus edodes (Shiitake) mushrooms which have the potential to be used medically from agricultural wastes. In this study, oak and beech sawdust and hazelnut shells resulting from timber residues in Düzce province were evaluated as mushroom compost. Hazelnut shells were milled in Wiley mill. Beech and oak sawdust was obtained from a timber factory. Composts were prepared by mixing wood sawdust and hazelnut shells in certain proportions. The prepared composts were sterilized by autoclaving at $121^{\circ} \mathrm{C}$ at 1.1 atm. The mushroom micelle inoculated composts were stored at $26^{\circ} \mathrm{C}$ and $80 \%$ relative humidity. After completing the incubation period, they were kept at $5^{\circ} \mathrm{C}$ and taken back to the cultivation room to form a promordium. According to the results obtained, it was found that the fungi produced with $100 \%$ hazelnut shell give lower values in terms of yield than oak and beech sawdust. However, the productivity and biological efficiencies obtained from the mixture of hazelnut shells with the other two materials in a ratio of 1: 1 are approximately the same ratio as those of fungi produced from oak and beech sawdust. The highest productivity
\end{abstract}


and biological activity values were obtained from oak wood compost. According to the results of chemical content, hazelnut shells and mixtures have the highest values in terms of total nitrogen and protein. No significant difference was found between compost mixtures in terms of total energy, carbohydrate and fat ratios.

Keywords: Lentinus edodes (Shiitake), medicinal mushroom, Hazelnut shell, beech sawdust, oak sawdust

\section{GIiRIS}

Yenilebilir mantarlar çok eski zamanlardan beri hem içerdikleri besin maddeleri hem de lezzetlerinden dolayı tüketilmektedir. Günümüzde de sağlığa faydalı besinler arasında önemli bir yer tutmaktadır. Kültür mantarcıllı̆̆ birçok ülkede önemli bir endüstri kolu haline gelerek ekonomik önem kazanmıştır. Üretimi yapılan mantar türlerinin sayısı ve miktarı ise her geçen gün artmaktadır [1,2]. Dünyada farklı ülkelerde yaklaşık olarak 35 mantar türünün ticari ve endüstriyel olarak üretimleri yapılmaktadır $[3,4]$. En fazla kültürü yapılan mantar türlerinin Agaricus spp., Pleurotus spp. ve Lentinus edodes olduğu belirtilmektedir [5].

Mantarlar, birçok yapısal özelliğe sahip materyali (ölü bitkileri, ölü hayvanları, boyaları, ayakkabıları, plastikleri, kağıtları, kıyafetleri) ayrıştırabilme özelliğine sahiptirler. Bu nedenle kültür mantarcılığında çok çeşitli materyaller kullanıma elverişlidirler. Düşük değere sahip tarımsal ve orman atıklarının yenilebilir kültür mantarcılığında değerlendirilmesi ekonomik açıdan önemli olup, oldukça etkili bir yöntemdir [6].

Lignoselülozik tarımsal artıkların, çevresel problemlere yol açtığı ve işlenmesi sürekli problem oluşturduğu bilinmektedir. Bunun en önemli nedeni, onların kimyasal yapısının kompleks ve ayrışmalarının ise zor olmasından ileri gelmektedir. Bu atıkları, mantar gibi değerli ürünlere biyolojik yolla dönüştürme potansiyeli son yıllarda daha çok vurgulanmıştır [6]. Yenilebilir mantarların, uygun enzimatik mekanizmalarıyla karmaşık organik molekülleri basit bileşiklere dönüştürebilirler [7].

Mantarlar, $\mathrm{Ca}, \mathrm{P}, \mathrm{K}, \mathrm{Fe}$ ve $\mathrm{Cu}$ gibi mineral maddeleri içerisinde barındırabilmektedir. Düşük karbonhidrat ve yağ oranı nedeniyle kalp ve damar hastalıklarında, kandaki şeker düzeyini düşürme özelliği nedeniyle de şeker hastalığında diyet özelliği vardır [8].

\section{A. ŞITTAKİ (SHIITTAKE) MANTARI}

Taze ve kurutularak tüketilebilen L. edodes mantarı bugün Çin başta olmak üzere Japonya, Orta Doğu, Asya, Avrupa ve Amerika'da üretimi hızla artmaktadır [9]. Bu mantarın vitamin, protein ve mineral maddeler bakımından oldukça zengindir. Bunun yanında bünyesinde bulunan lentinan maddesinin 'Sarcoma-180' kanser tedavisinde olumlu sonuç verdiği belirtilmiştir. Bu mantarın tedavi edici özelliği nedeniyle uzak doğu ülkelerinde tıp alanında geniş ölçüde kullanıldığı bildirilmiştir [10].

Kültürü yapılabilen en popüler üçüncü yenilebilir mantar olarak kabul edilen şitaki mantarının [2] dünyadaki toplam ticari üretimi, 1978-2003 yıllarında on iki kat artmıştır. 1978'de 1.060.000 ton iken 2003 'te yaklaşık olarak 14.274.000 ton olmuştur.

L. edodes mantarı torba kültüründe talaş, yonga, züruf gibi kompost ortamları üzerinde mevsime bağlı kalmaksızın yıl boyu üretimi mümkün olabilmektedir [11]. Torba kültürü ülkelerin öz hammadde kaynaklarına göre kompost içerikleri farklılık göstermektedir. Şitaki üretiminde meşe, çam, kavak, kayın, akçaağaç ve huş gibi ağaç türlerinin talaşı, hububat samanı, mısır koçanı, çay artığı, kahve pulpu, 
ayçiçeği tohum kabuğu ve pamuk tohumu atıkları gibi birçok tarımsal artık kullanılabilme potansiyeline sahiptir [10, 12-16].

Bu çalışmada Batı Karadeniz Bölgesi'nde orman ürünlerini işleme sonrası açığa çıkan meşe ve kayın talaşı ile findık üretimi sonrası açığa çıkan fındık sert kabuğundan tıbbi ve yenilebilir mantarlardan olan L. edodes yetiştirilmiştir.

\section{MATERYAL VE METOT}

\section{A. KOMPOST MATERYALLERI}

Bu kapsamda kayın ve meşe talaşları, bölgede faaliyet gösteren kereste ve mobilya fabrikalarından, fındık kabukları ise findık işleme fabrikalardan temin edilmiştir. Mantar üretimlerinde, gerekli olan miseller yurt dışından mantar tohumu ithal eden bir firmadan talep edilmiştir.

\section{B. KOMPOSTLARIN HAZIRLANMASI}

Kompost hazırlanacak malzemeler Willey değirmeninde ögütülmüştür. Farklı mesh büyüklüklerinde elde edilen kayın ve meşe odun talaşı ve findık kabuğu tozları kompost ana maddesi olarak değerlendirilmiştir. İşlenen organik materyalin rutubeti \%75'e ulaşıncaya kadar bir hafta boyunca devamlı karıştırılarak ıslatılmıştır. Kompost karışımları Tablo 1'de gösterildiği şekilde 6 farklı ortam oluşturulmuştur.

Tablo 1. Çalışmada kullanılan kompost materyalleri ve karışım oranları

Kompost formülü $\quad$ Karışım oranı (\%)

\begin{tabular}{ll}
\hline Findık Kabuğu (FK) & 100 \\
\hline Meşe Talaşı (MT) & 100 \\
\hline Kayın Talaşı (KT) & 100 \\
\hline Fındık Kabuğu: Kayın Talaşı (FK+KT) & $50 / 50$ \\
\hline Fındık Kabuğu: Meşe Talaşı (FK+MT) & $50 / 50$ \\
\hline Meşe Talaşı: Kayın Talaşı (MT+KT) & $50 / 50$ \\
\hline
\end{tabular}

Kompost karışımlarının daha sonra bir pH metre yardımıyla pH'ları ölçülmüştür. Sıcaklığa dayanıklı fırın poşetlerine doldurulan kompost karışımları $90^{\circ} \mathrm{C}$ 'de 1.5 saat pastörize edilmiştir. Otoklav sonrası örnekler soğuduktan sonra şitaki mantar miselleri aşılanmıştır.

\section{KOMPOSTLARIN pH DEĞERLERI}

Yapılan çalışma kapsamında, fındık kabuğu, kayın talaşı, meşe talaşı ve bunların 1:1 karışımlarına ait kompostların $\mathrm{pH}$ değerleri Tablo 2'de görülmektedir. Mantar verimliliği ve biyolojik etkinlik bakımından değerlendirildiğinde en yüksek verim ve biyolojik etkinliğin meşe talaşı pH'ının 6.55 olduğu ortamda tespit edilmiştir. 
Tablo 2. Farklı kompost formülasyonlarına ait pH değerleri

\begin{tabular}{ll}
\hline Kompost formülü & pH \\
\hline FK & 6.64 \\
\hline MT & 6.55 \\
\hline KT & 6.35 \\
\hline (FK+KT) $(1: 1)$ & 6.58 \\
\hline (FK+MT) $(1: 1)$ & 6.63 \\
\hline (MT+KT) $(1: 1)$ & 6.43 \\
\hline
\end{tabular}

\section{MANTAR İNKÜBASYON DÖNEMI VE HASAT}

Her parametre için pastörize edilen $1 \mathrm{~kg}$ 'lık poşetlere $20 \mathrm{gr}(\%$ 2) tohumluk miseller eklenerek aşılama yapılmıştır. Aşılanan parametrelerde miseller poşetin her tarafını sarana kadar $25 \pm 1 \mathrm{C}^{\mathrm{o}}$ de \% 75-80 bağıl nem ihtiva eden bir inkübasyon odasında bekletilmiştir. Poşetler sürekli kontrol edilmiş ve hastalık oluşan poşetler ortamdan uzaklaştırılmıştır. Tamamıyla misel saran kompostlar buzlu su dolu bir kap içerisinde 12 saat süre ile bekletilmiştir. Kompostlar 12 saat sonra buzlu su içerisinden çıkarılarak yaklaşık $15 \mathrm{C}^{\mathrm{o}}$ sıcaklıkta \%80-85 bağıl nemde bekletilmiştir. Hasat zamanı gelen mantarlar sap kısmının kompost ile birleştiği noktadan kesilerek toplanmıştır. Elde edilen mantarların ağırlık ve ölçümleri yapıldıktan sonra kimyasal analizler için kurutulmuştur (Şekil 1).

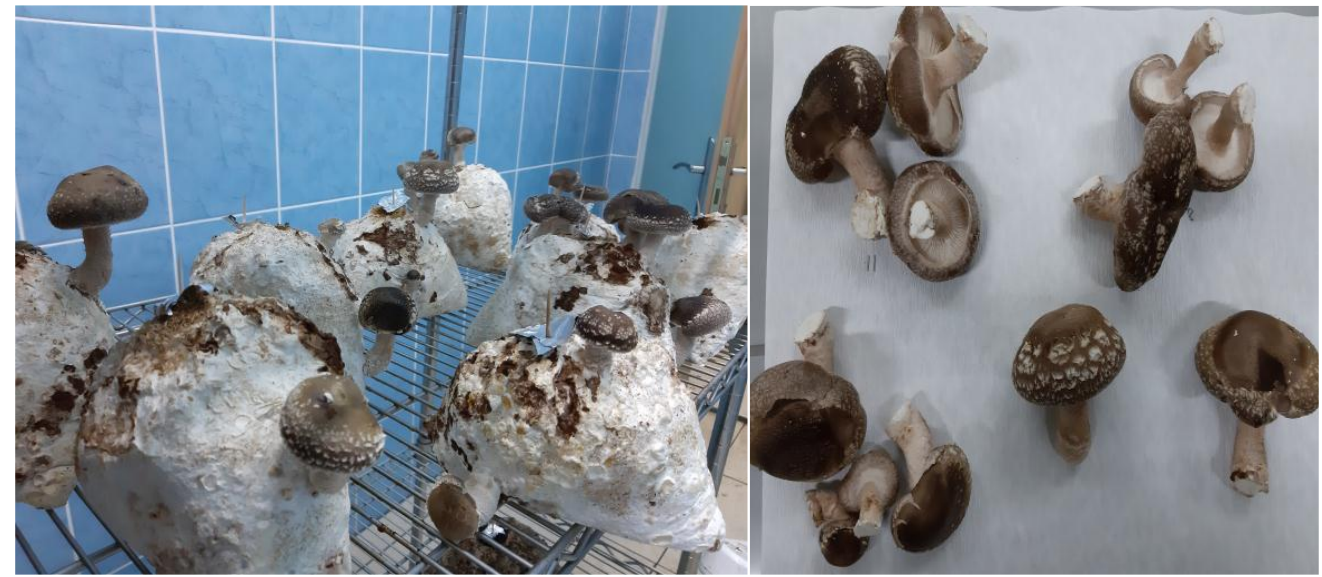

Şekil 1. Hasat dönemi ve hasat edilen mantarlar

\section{E. VERIM VE BIYYLOJIK ETKINLIK HESABI}

Tüm formülasyonlara ait mantar kompostlarından elde edilen mantarlar hasat sonrasında hassas terazi yardımıyla tartılmıştır. Elde edilen mantar ağırlıkları yardımıyla kompostların ilk flaşına ait verim ve biyolojik etkinlikleri aşağıdaki formüllere göre hesaplanmıştır.

Verim=Yaş Şapka Ağırlığı /Kuru Kompost Ağırlığı (Torba) gr/kg

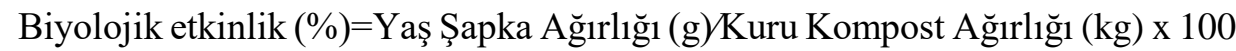

\section{F. MANTAR KALİTESİ İLE İLGILİ ANALİZ VE ÖLÇÜMLER}

F1. Şapka Genişliği: Şapkanın en geniş yerinden yapılan cetvel ölçümlerinin ortalamaları alınarak belirlenmiştir. 
F2. Sap Uzunluğu: Sapın şapkayla birleştiği kısımla ortam yüzeyine bağlandığı kısım arasındaki mesafenin cetvelle ölçülmesiyle belirlenmiştir.

F3. Ortalama mantar ăğırlğgi: Her bir torbadan hasat edilen mantarların ağıllıklarının tartılıp, mantar sayısına bölünmesiyle ortalama mantar ağırlığı bulunmuştur.

F4. Kuru madde tayini: Taze mantar ağırlıkları tartılmış, etüvde $105 \mathrm{C}^{\circ}$ de sabit ağırlığa ulaşıncaya kadar kurutulmuş ve etüvden çıkarılan örnekler desikatörde soğutulduktan sonra tekrar tartılarak hesaplanmıştır.

\section{G. BESIN DEĞERİ ANALIZLERI}

Elde edilen mantar şapka ve sapları kurutularak öğütülmüştür. Öğüntü tozları kimyasal ön işlemleri takriben, toplam azot miktarı (Kjeldahl metodu), ham protein miktarı, toplam kül miktarı, toplam su ve kuru madde miktarı, toplam yağ miktarı (Soksalet metodu), toplam karbonhidrat miktarı ve toplam enerji miktarları tespit edilmiştir.

\section{BULGULAR VE TARTISMMA}

\section{A. MANTAR VERIMII VE BIYYOLOJIKK ETKİNLİK}

Elde edilen mantar verimlerine ilişkin bulgular Şekil 2'de görülmektedir. En yüksek mantar verimliliği \%100 meşe talaşından hazırlanan kompostlardan (59 gr $/ \mathrm{kg})$ elde edilmiştir. \%100 findık kabuğu kompostu ise en düşük verimliliğe sahip olup ortalama $16 \mathrm{gr} / \mathrm{kg}$ (mantar yaş ağırllğı $/ \mathrm{kuru}$ kompost ağırlı̆̆ı) olarak hesaplanmıştır.

Daha önce yapılan bir çalışmada, meşe talaşı ortalama verimi $32.5 \mathrm{gr} / \mathrm{kg}$, ceviz kabuğu $11.8 \mathrm{gr} / \mathrm{kg}$ ve badem kabuğu $15.5 \mathrm{gr} / \mathrm{kg}$ olarak tespit edilmiştir. Ancak bu materyallerin birbirleri ile farklı oranlarda karıştırılmaları durumunda \%100 durumlarına göre daha yüksek verim değerleri verdiği tespit edilmiştir [17]. Yapılan bu çalışmadaki gerek meşe talaşı $(59.8 \mathrm{gr} / \mathrm{kg})$ ve kayın talaşı $(38.0 \mathrm{gr} / \mathrm{kg})$ gerekse bunların karışımlarından (48 gr/kg) elde edilen verim değerleri Düzkale Sözbir [17]'in çalışmasına göre daha yüksek bulunmuştur.

Yapılan diğer çalışmalarda ise, verim değerleri pirinç kabuğunda $220.2 \mathrm{gr} / \mathrm{kg}$ ve şeker kamışında 15.1 gr/kg [18], fındık kabuğu 169.24 gr/kg [19], asma budama artıklarında 37.46 gr/kg [20] olarak elde etmişlerdir. Bu çalışmalar dikkate alındığında, mevcut çalışmada fındık kabuğu verim değerlerinin (16.2 $\mathrm{gr} / \mathrm{kg}$ ) çok daha düşük olduğu söylenebilir.

Farkl1 formülasyonlarda hazırlanan kompostlara ait biyolojik etkinlik değerleri Şekil 2'de görülmektedir. Elde edilen sonuçlara göre verimlilikte olduğu gibi en yüksek biyolojik etkinlik meşe talaşı ve karışımlarından elde edilirken, \%100 findık kabuğu diğer karışımlara göre oldukça düşük biyolojik etkinlik göstermiştir.

Daha önce yapılan bir çalışmada ortalama biyolojik etkinlik oranı, meşe talaşında $\% 12,7$, ceviz kabuğu $\% 1,97$ ve badem kabuğu \%2,29 olarak tespit edilmiştir [17]. Ayrıca pirinç kabuğunda \% 22,01, pirinç sapında $\%$ 4,07, şeker kamışında \% 1,51 [18], findık kabuğunda \% 43,73 [19], asma budama atıklarında $\% 93,25$ [20], farklı ortamlarda \% 41,07, \% 75,23, \% 80,64 [21] ve yine değişik ortamlarda \% 76,6 [22] olarak belirlemişlerdir.

Literatür çalışmaların sonuçları, bu çalışmanın sonucu ile karşılaştırıldığında, farklı ortamlarda elde edilen mantarların biyolojik etkinlik oranı farklılık göstermiştir. Biyolojik etkinlik oranı, verim değeri ile doğru orantılı olduğundan, biyolojik etkinlik değeri daha önceki yapılan çalışmalarla kıyaslandığında 
düşük çıktığı görülmektedir. Fakat bu çalışmadaki değerler sadece bir hasat dönemi değeridir. Toplam hasat miktarları ile kıyaslanacak olursa biyolojik etkinlik oranının da artması beklenir.

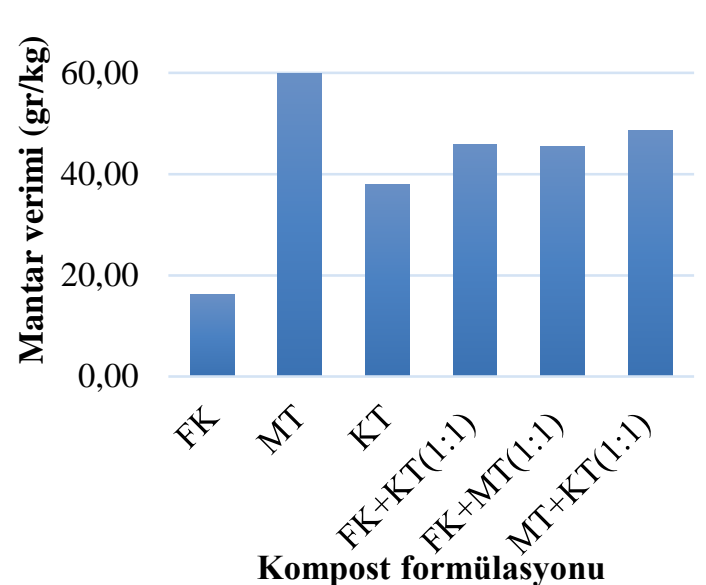

Kompost formülasyonu

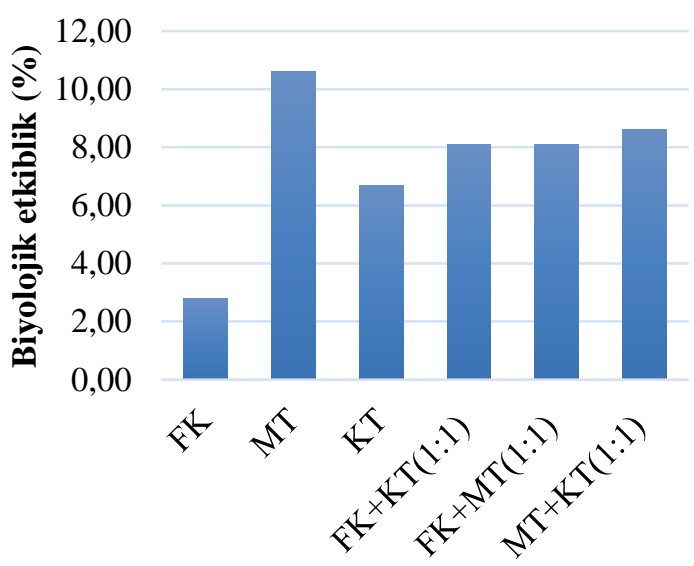

Kompost formülasyonu

Şekil 2. Farklı kompost formülasyonlarına göre ortalama mantar verim ve biyolojik etkinlik

\section{B. MANTAR SAP UZUNLUKLARI VE ŞAPKA GENIŞLIKLERİ}

Üretilen mantarların ortalama sap uzunlukları karşılaştırıldığında, kompost formülasyonlarının birbirlerine göre farklılıklar gösterdiği görülmektedir (Tablo 3). En düşük sap uzunluğu, fındık kabuğu kayın talaşı (1:1) karışımı olan komposttan üretilen mantarlarda tespit edilmiştir. Genel olarak bakıldığında, fındık kabuğu ve karışımlarının diğer materyallere göre daha düşük sap uzunluğu verdiği görülmektedir.

Daha önce yapılan birçok çalışmada, şitaki mantarların ortalama sap uzunluklarının $5,8 \mathrm{~cm}$ ile $7.1 \mathrm{~cm}$ arasında olduğu belirtilmiştir. Ayrıca Özçelik ve Pekşen [10] yaptıkları çalışmalarda, mantarın sap uzunluklarının $4.1 \mathrm{~cm}$ ile $7.1 \mathrm{~cm}$ arasında değiştiğini belirtmişlerdir. Düzkale Sözbir [17], yaptı̆̆ diğer bir çalışmada ise, farklı kompost materyali karışımlarından elde edilen mantarların sap uzunluklarının $3.2 \mathrm{~cm}$ ile $5.0 \mathrm{~cm}$ arasında değiştiğini belirtmiştir. Belirtilen çalışmalar ile kıyaslandığında mantar sap uzunluklarının literatür ile uygunluk gösterdiği görülmektedir.

Mantar şapka genişliği bakımından farklı kompost karışımlarına ait bulgular Tablo 3'te görülmektedir. Elde edilen bulgulara göre findık kabuğu: meşe talaşı (1:1) ve findık kabuğu: kayın talaş1 (1:1) kompost karışımlarından diğer varyasyonlara göre daha geniş şapka elde edilmiştir.

Özçelik ve Pekşen, [10] findık zürufu, kayın talaşı, buğday samanı, kepek ve darı ile yaptıkları çalışmalarda şapka genişlikleri, $1.6 \mathrm{~cm}$ ile $2,9 \mathrm{~cm}$ arasında değiştiği belirtmelerine rağmen, Ashrafuzzaman ve ark. [23], Bengali yöresine ait bitkisel materyaller ile yaptıkları çalışmalarda şapka genişliklerinin $4.1 \mathrm{~cm}$ ile $4.9 \mathrm{~cm}$ arasında, Moonmoon ve ark. [22] ise buğday kepeği, pirinç kepeği ile mısır tozu üzerinde yaptıkları çalışmada $3.4 \mathrm{~cm}$ ile $6.0 \mathrm{~cm}$ arasında değiştiği belirlenmiştir. Bu çalışmada elde edilen bulgulara göre mantarlar şapka genişliklerinin $5.5 \mathrm{~cm}$ ile $7.7 \mathrm{~cm}$ arasında değiştiği ve daha önceki belirtilen çalışmalara göre daha büyük şapka elde edildiği görülmektedir. Ancak Düzkale Sözbir [17]'in yaptığı çalışma ile karşılaştırıldığında $(5.5 \mathrm{~cm}$ ile $9.6 \mathrm{~cm})$ şapka genişliklerinin benzerlik gösterdiği söylenebilir. 
Tablo 3. Farklı kompost formülasyonlarına göre ortalama mantar sapı uzunlukları ve şapka genişlikleri (cm).

\begin{tabular}{ccc}
\hline Kompost formülü & Ortalama Sap Uzunluğu & $\begin{array}{c}\text { Ortalama Şapka } \\
\text { Genişliği }\end{array}$ \\
\hline FK & $3.7(1.4)$ & $5.5(0.6)$ \\
\hline MT & $4.3(1.3)$ & $6.8(0.9)$ \\
\hline KT & $4.3(1.1)$ & $6.3(1.3)$ \\
\hline (FK+KT) $(1: 1)$ & $3.5(0.7)$ & $7.7(1.2)$ \\
\hline (FK+MT) $(1: 1)$ & $4.1(2.1)$ & $7.7(1.1)$ \\
\hline (MT+KT) $(1: 1)$ & $4.4(1.3)$ & $6.3(0.6)$ \\
\hline
\end{tabular}

Şapka genişliğindeki farklılıklar mantarların hasat döneminin uzatılması ve yetişme şartlarındaki farklılıklardan kaynaklanabilmektedir. Tüm kompost formülasyonlarından elde edilen mantarlar şekil 3'te gösterilmiştir.
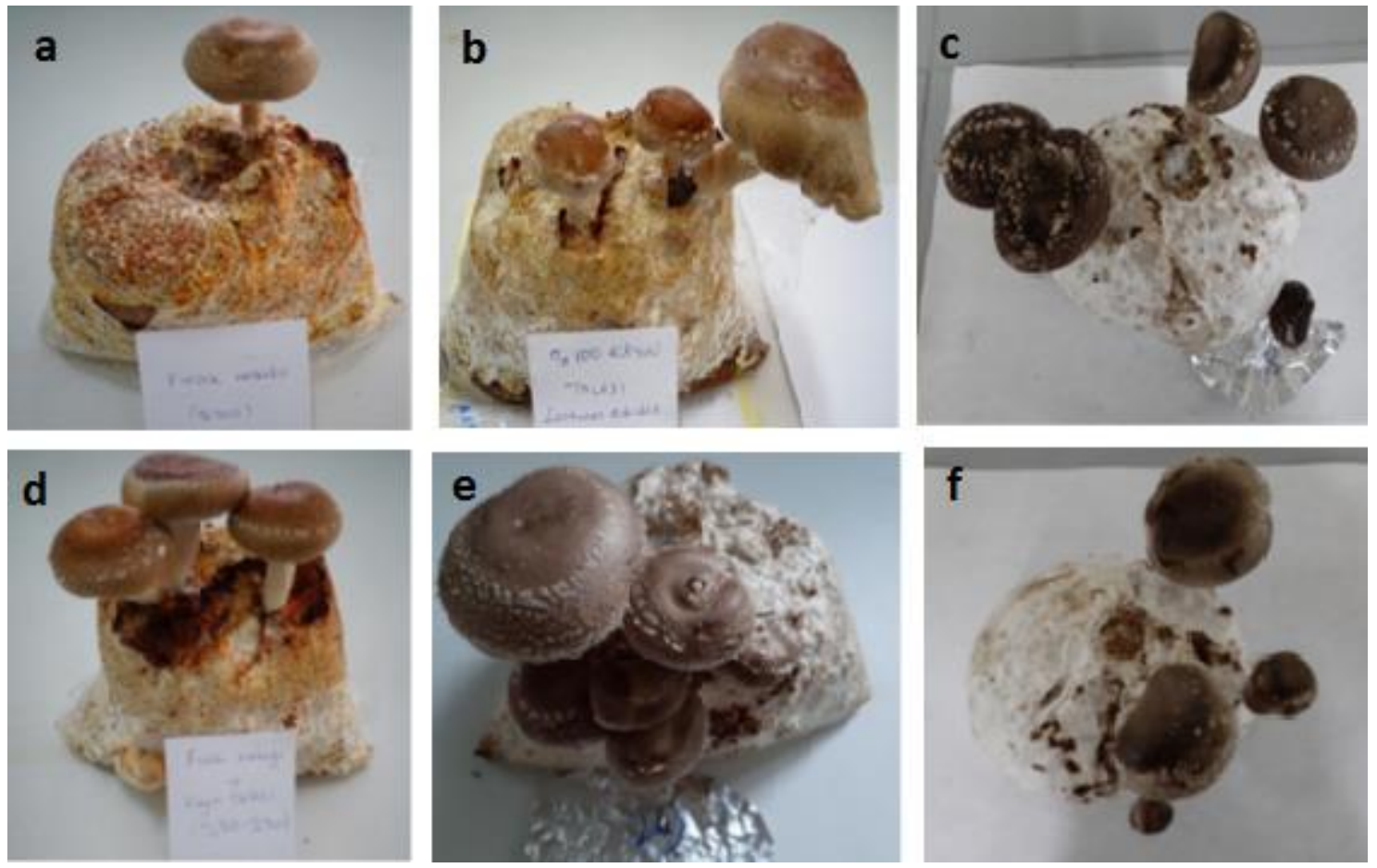

Şekil 3. Kompost formülasyonlarından elde edilen şitaki mantarları

a) \%100 findık kabuğu, b) \%100 kayın talaşı, c) \%100 meşe talaşı d) \%50 Findık zürufu:\%50 Kayın talaşı, e) \%50 Fındık kabuğu: \%50 Meşe talaşı f) \%50 Kayın talaşı: \%50 Meşe talaşı

\section{KIMYYASAL ANALIZLERE AIT BULGULAR}

Meşe ve kayın talaşlarının \%100 oranında kullanıldığı kompostlardaki toplam azot miktarı bu materyalleri fındık kabuğu ile 1:1 oranında karıştırıldığı kompostlardaki toplam azot miktarı arasında farklılık ortaya çıkmıştır. Fındık kabuğu karışımlarının toplam azot miktarı diğer kompostlara göre daha yüksek çıktığı görülmektedir (Tablo 4).

Ham protein oranı ile toplam azot miktarı arasında bir benzerlik söz konusu olup, en fazla ham protein oranı \%100 findık kabuğu ve findık kabuğu: meșe talaşı (1:1)'den elde edildiği tespit edilmiştir (Tablo 4). Daha önce yapılan çalışmalarda ham protein miktarı \%17.5-32.3 [17], \% 11.03 ile 19.87 [24], \% 12.37 ile $\% 17.19$ [20] ve 19.25 ile $21.24 \mathrm{~g} / 100$ [25], \% 15.60 ile \% 25.72 [10 ] olarak bulunmuştur. Yapılan bu çalışma ile karşılaştıııldığında, protein oranının literatür ile benzerlik göstermekle birlikte bazı çalışmalardan elde edilen bulgulara göre daha düşük değerler elde edildiği de görülmektedir. 
Toplam karbonhidrat oranı bakımından incelendiğinde findık kabuğu ve karışımlarından üretilen mantarların karbonhidrat oranının diğer kompost karışımlarına göre nispeten daha düşük değerler verdiği görülmektedir. Ranjbar ve ark. [26] yapmış oldukları bir çalışmada toplam karbonhidrat değerlerinin \%17 ve \%83 arasında tespit etmişlerdir. Toplam karbonhidrat değerleri Ranjbar ve ark. [26]' nın çalışmasıyla kıyaslandığında toplam karbonhidrat oranının tüm kompost oranlarında yüksek düzeyde olduğu görülmüştür.

Toplam enerji bakımından değerlendirildiğinde ise kayın talaşının \%100 kompostunda ve fındık kabuğu ile meşe talaşının (FK+MT) (1:1) kompostunda diğer kompost formülasyonlarına göre daha yüksek değerler verdiği tespit edilmiştir.

Tablo 4. Kompost karışımlarına göre elde edilen mantarların besin değerleri.

\begin{tabular}{cccccc}
\hline & \multicolumn{3}{c}{$\%$} & & \\
\hline Kompost & $\begin{array}{c}\text { Toplam } \\
\text { azot } \\
\text { miktarı }\end{array}$ & $\begin{array}{c}\text { Ham protein } \\
\text { miktar }\end{array}$ & $\begin{array}{c}\text { Toplam yag } \\
\text { miktarı }\end{array}$ & $\begin{array}{c}\text { Karbohidrat } \\
\text { miktarı }\end{array}$ & $\begin{array}{c}\text { Toplam enerji } \\
\text { (kcal) }\end{array}$ \\
\hline FK & 3.11 & 19.43 & 0.75 & 62.47 & 334.35 \\
\hline MT & 1.78 & 11.12 & 0.80 & 66.30 & 316.88 \\
\hline KT & 1.74 & 10.87 & 0.62 & 72.78 & 340.18 \\
\hline$($ FK+KT) $(1: 1)$ & 2.51 & 15.68 & 0.80 & 60.89 & 313.48 \\
\hline$($ FK+MT) $(1: 1)$ & 0.69 & 4.31 & 0.85 & 78.72 & 339.77 \\
\hline$($ MT+KT) $(1: 1)$ & 2.99 & 18.68 & 0.65 & 62.20 & 329.37 \\
\hline
\end{tabular}

Mantar şapkalarının toplam kül, toplam su miktarı ve toplam kuru madde miktarı Tablo 5 'te verilmiştir. Elde edilen sonuçlara göre en fazla toplam kuru madde miktarı \%19.66 ile meşe talaşı (\%100) formülasyonunda, en az ise \%12.4 ile kayın talaşı (\%100) formülasyonunda tespit edilmiştir. Toplam kül miktarına bakıldığında ise en fazla kül miktarı \%4.89 ile fındık kabuğu + meşe talaşı $(1: 1)$ formülasyonunda en az ise \%2.12 ile Meşe talaşı (\%100) formülasyonunda tespit edilmiştir. Salmones ve ark. [27] yaptıkları çalışmada toplam kül miktarını \% 6,2 ile \% 7,1 arasında, toplam su miktarını ise $\%$ 83,9 ile \% 92,3 arasında tespit etmişlerdir. Kül miktarının Salmones ve ark. [27]'nın çalışması ile kıyaslandığında daha düşük değerler verdiği, toplam su miktarının ise benzerlik gösterdiği tespit edilmiştir.

Tablo 5. Kompost karışımlarına göre elde edilen mantarlara ait toplam su/kuru madde oranları (\%).

\begin{tabular}{cccc}
\hline \multicolumn{1}{l}{ Kompost } & Toplam kül miktarı & Toplam su miktarı & Toplam kuru madde miktarı \\
\hline FK & 2.57 & 85.22 & 14.78 \\
\hline MT & 2.12 & 80.34 & 19.66 \\
\hline KT & 3.33 & 87.6 & 12.4 \\
\hline$($ FK+KT) $(1: 1)$ & 3.47 & 80.84 & 19.16 \\
\hline$($ FK+MT) $(1: 1)$ & 3.06 & 86.94 & 13.06 \\
\hline$(\mathrm{MT}+\mathrm{KT})(1: 1)$ & 4.89 & 86.42 & 13.58 \\
\hline
\end{tabular}

\section{IV.SONUC}

Yapılan bu çalışmadan elde edilen sonuçlara göre, Lentinus edodes tıbbi ve yenilebilir mantarının meşe talaşı, kayın talaşı ve fındıkkabuğu gibi lignoselülozik materyallerden üretilebilme potansiyeline sahip olduğu görülmüsstür. Ancak bu materyallerden hazırlanan kompostlardan üretilen mantarların kalite ve diğer kimyasal içeriklerinde farklılıkların olduğu tespit edilmiştir. Özellikle \%100 findık kabuğu ile üretilen mantarların meşe ve kayın talaşına göre verim bakımından düşük değerler verdiği tespit edilmiştir. Ancak fındık kabuğunun diğer iki materyal ile 1:1 oranında karışımlarından elde edilen 
verimlilik ve biyolojik etkinlik değerleri meşe ve kayın talaşından üretilen mantarlarınki ile yaklaşık aynı oran/değerlerdedir. En yüksek verimlilik ve biyolojik etkinlik değerleri meşe talaşı kompostundan elde edilmiştir. Kimyasal içerik bakımından elde edilen sonuçlara göre ise toplam azot ve protein bakımından fındık kabuğu ve karışımları en yüksek değerlere sahiptir. Toplam enerji, karbonhidrat ve yağ oranları bakımından ise kompost karışımları arasında önemli sayılabilecek farklılık tespit edilmemiştir. Atık olarak ortaya çıkan findık kabuğunun farklı oranlarda meşe ve kayın talaşlarına karıştırılmasıyla şitaki mantarı üretiminde değerlendirilebilir.

TEȘEKKÜR: Bu çalışma, Yükseköğretim Kurulu Başkanlığı tarafından koordine edilen ve Kalkınma Bakanlığı ile birlikte eşgüdüm halinde yürütülen "Üniversitelerin Bölgesel Kalkınma Odaklı Misyon Farklılaşması ve İhtisaslaşması" temalı proje çalışması kapsamında "Düzce Üniversitesi Çevre ve Sağlık Teknolojilerinde İhtisaslaşma Koordinatörlüğü" ile "2018.2.3.668 nolu BAP projesi” tarafından desteklenmiştir.

\section{KAYNAKLAR}

[1] S. Şen, Y. Çöpür, C. Taş̧̧ıoğlu and M. Akgül, "Utilization of Recycled Container Box for Pleurotus ostreatus (Oyster Mushroom) Production," First International Workshop, Novel Technologies in Pulp and Paper Industry, 2005, Kahramanmaraş, Turkey.

[2] E. Eren ve A. Pekşen, “Türkiye'de Kültür Mantarı Sektörünün Durumu ve Geleceğine Bakış,” Türk Tarım - Gida Bilim ve Teknoloji Dergisi, c. 4, s. 3, ss. 189-196, 2016.

[3] C. Sanchez, "Mini-Review: Modern Aspects of Mushroom Culture Technology," Applied Microbiology and Biotechnology, c. 64, s. 6, ss. 756-762, 2004.

[4] G.Y. Turp ve M. Boylu. "Tıbbi ve Yenilebilir Mantarlar \& Et Ürünlerinde Kullanımı,” Yüzüncü Yll Üniversitesi Tarım Bilimleri Dergisi, c. 28, s. 1, ss. 144-153, 2018.

[5] V.A. Diez and A. Alvarez, "Compositional and Nutritional Studies on Two Wild Edible Mushrooms from Northwest Spain," Food Chemistry, c. 75, s. 4, ss. 417-422, 2001.

[6] A. Dündar, "Lokal Tarımsal Artık Materyaller Kullanılarak Pleurotus ostreatus (Jacq.) Kumm. (Kültür Mantarı)'Un Üretilmesi Konusunda Bir Araştırma," Yüksek Lisans Tezi, Dicle Universitesi, Fen Bilimleri Enstitüsü, Diyarbakır, Türkiye, 2006.

[7] A. T. Martinez, S. Camarero, F. Guillen, A Gutierrez, C. Munoz, A. Varela, M. J. Martinez, J. Barrasa, K. Ruel, and J. Paleyo, "Progress in Biopulping of Non-woody materials: Chemical, Enzymatic and Ultrastructural Aspects of Wheat Straw Delignification with Ligninolytic Fungi From The Genus Pleurotus," FEMS Microbiology Reviews, c. 13, s. 2-3, ss. 265-274, 1994.

[8] S. Şen ve M. Yalçın, "Dünya ve Türkiye'de Kültür Mantarcılığı ve Geliştirilmesi," III. Ulusal Karadeniz Ormancllık Kongresi, c. 3, ss. 1208-1216, 2010.

[9] J. D. Royse and E. J. Sanchez-Vazquez, "Influence of Substrate Wood-chip Particle Size on Shiitake (Lentinus edodes) Yield," Biosesource Technology, c. 76, s. 3, ss. 229-233, 2001.

[10] E. Özçelik and A. Pekşen, "Lentinus edodes Yetiştiriciliğinde Fındık Zurufundan Hazırlanan Farklı Yetiştirme Ortamlarının Verim ve Bazı Mantar Özelliklerine Etkileri," Ondokuz Mayıs Üniversitesi Ziraat Fakültesi Dergisi, c. 21, s. 1, ss. 65-70, 2006. 
[11] M.E. İlbay, "Lentinus edodes Kültür Mantarı Yetiştiriciliğinde Değişik Yetiştirme Ortamları ve Katk1 Maddelerinin Verim ve Kaliteye Etkileri Üzerinde Araştırmalar," Doktora Tezi, Ankara Üniversitesi Fen Bilimleri Enstitüsü, Ankara, Türkiye, 1994.

[12] A. Auetragul, "The Highest Aspects For Cultivating Oak Mushroom (L. edodes) in Plastic Bags," Mushroom Newsl. Trop, c. 5, s. 11, ss. 11-15, 1984.

[13] D.A. Diehle and D.J. Royse, "Shiitake Cultivation on Sawdust: Evaluation Of Selected Genotypes for Biological Efficiency and Mushroom Size," Mycologia, c. 78, s. 6, ss. 929-933, 1986.

[14] M. Lesko-Biro. "Studies on the Sybstrae Requirement of Shiitake (Lentinus edodes). Zoldsegtermesztesi KutatoIntezet Bulletinje," s. 24, ss. 111-115, 1991.

[15] S. Balazs and M. Kovacs-Gyenes, "Cultivation Trials with Shiitake (Lentinus edodes) mushrooms," Zoldsegtermesztesi Kutato Intezet Bulletinje, c. 25, ss. 5-13, 1993.

[16] M. Sobal, P. Morales,W. Martinez, D.N. Pegler and D. Martinez-Carrera, "Cultivation of Lentinus levis in Mexico," Micologia Neotropical Aplicada, c. 10, ss. 63-71, 1997.

[17] G. Düzkale Sözbir, "Farklı Besin Ortamlarının Lentinus edodes (Shiitake) Mantarında Verim, Lentinan ve Kimyasal Bileşimine Etkileri," Doktora Tezi, Orman Endüstri Mühendisliği Bölümü, Kahramanmaraş Sütçü İmam Üniversitesi, Kahramanmaraş, Türkiye, 2014.

[18] L. Ramkumar, P. Thirunavukkarasu and T. Ramanathan, "Development of Improved Technology for Commercial Production and Preservation of Shiitake Mushroom (Lentinus edodes)," American-Eurasian Journal of Agricultural and Environmental Sciences, c. 7, s. 4, ss. 433-439, 2010.

[19] E. Özçelik, and A. Peşken, "Hazelnut Husk as a Substrate for The Cultivation of Shiitake Mushroom (Lentinula edodes)," Bioresource Technology, c. 98, ss. 2652-2658, 2007.

[20] R. Gaitan-Hernandez, M. Esqueda, A. Gutıérrez, A. Sánchez, M. Beltrán-Garcĺa and G. Mata, "Bioconversion of Agrowastes by Lentinula edodes: the High Potential of Viticulture Residues," Applied Microbiol Biotechnology, c. 71, ss. 432- 439, 2006.

[21] D. J. Royse and J. E. Sanchez, "Ground Wheat Straw As Aa Substitute For Portions of Oak Wood Chips Used in Shiitake (Lentinula edodes) Substrate Formulae," Bioresource Technology, c. 98, ss. 2137-2141, 2007.

[22] M. Moonmoon, N. J. Shelly, A. Khan., N. Udin, K. Hossain, M. Tania and S. Ahmed, ”Effect of Different Levels of Wheat Bran, Rice Bran And Maize Powder Supplementation With Saw Dust on The Production of Shiitake Mushroom," Saudi Journal of Biological Sciences, c. 18, s. 4, ss. 323-328, 2011.

[23] M. Ashrafuzzaman, A.K.M, Kamruzzaman, R. M, Ismail and S. M. Shahidullah, "Comparative Studies on The Growth and Yield of Shiitake Mushroom (Lentinus edodes) on Different Substrates," Advances in Environmental Biology, c. 3, s. 2, ss. 195-203, 2009.

[24] A. Philippoussis, P. Diamantopoulou and C. Israilides. "Productivity of Agricultural Residues Used for The Cultivation of The Medicinal Fungus Lentinula edodes," International Biodeterioration \& Biodegradation, c. 59, s. 7, ss. 216-219, 2007.

[25] G. Xiao-Hui, X. Chun-Yan, T. Yu-Rong, C. Long, M. Jian. "Mathematical Modeling and Effect of Various Hot-Air Drying on Mushroom (Lentinus edodes)," Journal of Integrative Agriculture, c. 13 s. 1, ss. 207-216, 2014. 
[26] M.E. Ranjbar, J.A. Olfati, M. Amani. "Influence of Enriched Soak-Ing Water on Shiitake (Lentinus edodes (Berk.) Singer) Mushroom Yield and Properties," Acta Agriculturae Slovenica, c. 1093, s. 5, ss. 555-560, 2017.

[27] D. Salmones, G. Mata, L.M. Ramos, and K.N. Waliszewski, "Cultivation of Shiitake Mushroom, Lentinula edodes, in Several Lignocellulosic Materials Originating from the Subtropics," Agronomie, c. 19, s. 1, ss. 13-19, 1999. 